
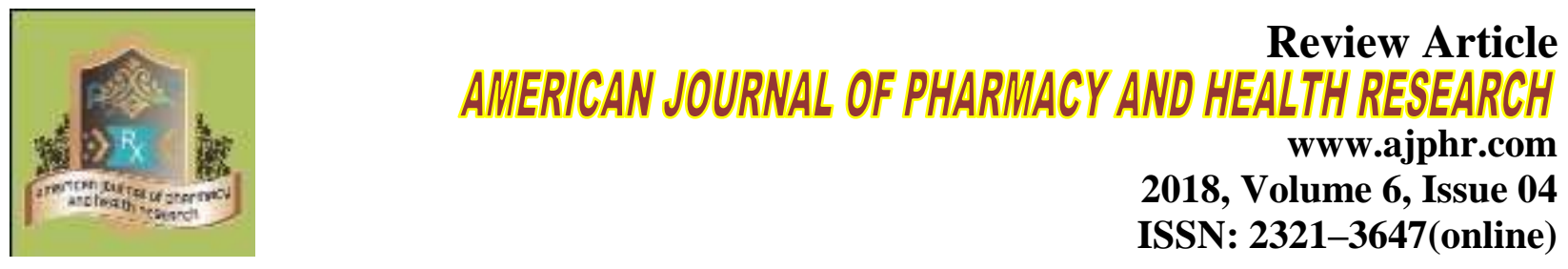

\title{
Free Radicals and their Management
}

\author{
Majaz A. Qazi ${ }^{1 *}$, Khurshid I. Molvi ${ }^{2}$ \\ 1.Ali- Allana College of Pharmacy Akkalkuwa, District Nandurbar, MS, India \\ 2.Ibn. Sina National College for Medical Studies, Jeddah, Kingdom of Saudia Arabia
}

\begin{abstract}
Free radicals are molecules containing one or more unpaired electrons in their outmost atomic or molecular orbital have emerged as double edged swords. current investigation showed that they can be both beneficial (e.g. required for normal physiological functioning) or deleterious (e.g. produce oxidative stress and responsible for various disease). Thus, it is important to understand all the aspects of free radicals while working in the this field. The present review provides a brief overview on free radicals and their role in normal physiology, oxidative stress, antioxidants and their evaluation.
\end{abstract}

Keywords: Free radicals, Antioxidant, Oxidative stress 


\section{INTRODUCTION}

Free radicals can be defined as atoms or molecules or molecular fragments containing one or more unpaired electrons in their atomic or molecular orbitals. Generally it is considered than around 10000-20000 free radicals attacking every cell every day out of which some are good for health which enable human body to fight inflammation, kill bacteria, controls smooth muscles which regulate the proper functioning of internal organs and blood vessels. On the other hand free radicals play vital role in pathogenesis of various diseases such as heart disease, diabetes mellitus, Alzheimer disease, Parkinson disease, cancer, arthritis and aging etc if produced in large or uncontrolled manner. ${ }^{1}$

Reactive oxygen species (ROS) and reactive nitrogen species (RNS) are free radicals generated physiologically in human body which having different types mention in following. ${ }^{2}$

\section{* $\quad$ Reactive oxygen species (ROS)}

- Superoxide $\left(\mathrm{O}_{2}\right)$,

- Hydrogen peroxide $\left(\mathrm{H}_{2} \mathrm{O}_{2}\right)$

- Hydroxyl radical (HO)

- Peroxyl radical $\left(\mathrm{RO}_{2}\right)$

- Alkoxyl radical (RO)

- Hydroperoxyl radical $\left(\mathrm{HO}_{2}\right)$

- Singlet oxygen $\left({ }^{1} \mathrm{O}_{2}\right)$

- Ozone $\left(\mathrm{O}_{3}\right)$

\section{* $\quad$ Reactive nitrogen species (RNS)}

- Nitric oxide (NO)

- Nitrogen dioxide $\left(\mathrm{NO}_{2}\right)$

- Nitrous acid $\left(\mathrm{HNO}_{2}\right)$

- Dinitrogen tetroxide $\left(\mathrm{N}_{2} \mathrm{O}_{4}\right)$

- Dinitrogen trioxide $\left(\mathrm{N}_{2} \mathrm{O}_{3}\right)$

- Peroxynitrite (ONOO)

- Peroxynitrous acid (ONOOH)

- Alkyl peroxynitrites (ROONO)

- Nitronium cation $\left(\mathrm{NO}_{2}{ }^{+}\right)$

- Nitryl chloride $\left(\mathrm{NO}_{2} \mathrm{Cl}\right)$ 
The free radical formation is in the body is continuous and unavoidable process of human body.

The immune system, metabolic processes, stress, dietary factors, environment factors, toxins and some drugs are responsible for generation of free radicals. ${ }^{3}$

\section{The immune system}

Reactive oxygen species produced by immune defensive mechanism and utilize as weapons against various antigens

\section{Stress}

Stress condition in human being activates mitochondria functions which are mainly responsible for generation of free radicals.

\section{Metabolic process}

Metabolic process generates many reactive oxygen species generates as byproducts. Every cell having its own metabolic process which is continuous and abundant which results number of free radicals from every cell continuously.

\section{Dietary factors}

Alcohol, coffee, foods of animal origin, roasted foods, broiled foods, fried foods, grilled foods, browned or burned foods, herbicides and pesticides residue available in food, and hydrogenated vegetable oils etc accelerate free radical formation process.

\section{Environment factors}

Air pollutants (asbestos, tobacco smoke, carbon monoxide, benzene, etc.), chemical solvents (chlorine, formaldehyde, toluene, chloroform, paints, paint thinners etc.), radiations (cosmic radiation, electromagnetic radiation, $\mathrm{x}$-rays, radon gas, solar radiation) are all potent generator of free radicals.

\section{Toxins}

Carbon tetrachloride, Aniline dyes, Toluene etc are responsible for generation of free radicals.

\section{Drugs}

Some drug accelerates free radical formation process such as adriamycin, bleomycin, mitomycin $\mathrm{C}$, nitrofurantoin, and chlorpromazine.

\section{EFFECT OF FREE RADICAL ON BODY}

Each and every cell present in body produces free radical hence prone to free radical attack. Biological compounds available in human changes their property after free radical attack which may alter cellular function of human body and even leads to death of cells or tissue which responsible for generating various diseases. The most susceptible biological compounds' are lipid, protein, DNA etc., ${ }^{3,4}$ 


\section{Lipids}

Free radical reacts with lipids available in subcellular parts produces peroxidation reaction and generates free radicals which alter fluidity and permeability of membrane can also affect functions of enzymes and receptors due to presence of membrane bound proteins. During lipid peroxidation reaction some toxic products also formed which can act as second messengers i.e. they can produce their toxic effect away from site of generation. ${ }^{3,4}$

Lipid peroxidation involves no of reaction in sequence which starts with abstraction of hydrogen atom from methylene group $(\mathrm{CH} 2)$, results an unpaired electron on the carbon atom $(\bullet \mathrm{CH})$. The carbon radical produces a stable conjugated diene molecular rearrangement, which react with an oxygen molecule to form a lipid peroxyl radical (LOO•). These radicals further abstract hydrogen atoms from other lipid molecules and produce lipid hydroperoxides (LOOH) thus initiating a new lipid peroxidation reaction. ${ }^{4}$

\section{Proteins}

Free radical direct attack on protein and initiate oxidation reaction results can affect many kinds of protein, interfering with enzyme activity and the function of structural proteins. The most of stable or functionally in active oxidized protein are rapidly removed and does not have any effect on human body. The unstable oxidized products such as protein hydroperoxides produce further radical by interacting with transition metal ions and gradually accumulate which responsible for various diseases i.e. Alzheimer's disease. ${ }^{4}$

\section{DNA}

When free radical comes in contact with DNA the C4-C5 double bond of pyrimidine is particularly attacked by $\bullet \mathrm{OH}$ and generates, thymine glycol, uracil glycol, urea residue, hydantoin etc. Similarly, purines generate formamido- pyrimidines, 8-hydroxy deoxyguanosine (8-OHdG), 8-hydroxy deoxyadenosine, etc. produce fragmentation of DNA causes activation of the poly (ADP-ribose) synthetase enzyme which produces $\mathrm{NAD}^{+}$for repairing of DNA. However, in many cases it is not possible results in alteration of cell functions and produce death. ${ }^{4}$

\section{ROLE OF FREE RADICALS IN NORMAL PHYSIOLOGICAL PROCESSES}

It play important role in phagocytosis, apoptosis, detoxification reactions as mediator and executioner of precancerous and infectious cells. It maintains cellular homeostasis in body by participating in various signaling pathways. Free radical control many metabolic and cellular processes including, oxygen sensing, proliferation, vascular contraction, wound healing, muscles contraction, gene expression, regulation of transcription, and signal transduction. It also involve 
in generation of biochemical reactions which are responsible for production of prostaglandins, hydroxylation of proline and lysine, oxidation of xanthine. ${ }^{5,6}$

\section{ROLE OF FREE RADICALS IN PATHOGENESIS OF DISEASES}

The concept of oxidative stress play important role in understanding the relation between free radicals and disease. The formation of free radicals in the form of ROS and RNS in a normal healthy condition effectively kept in control by the various levels of antioxidant defense (prevention, interception and repair). However, when human body comes in contact with physicochemical, environmental or pathological agents alter production rate of free radicals which resulting in oxidative stress. ${ }^{3,4}$

\section{Cancer}

Oxidative stress is responsible for alteration of DNA sequence resulting DNA mutation which is critical step in carcinogenesis. In various cancerous cell oxidative stress have been found more as compare to normal cells which indicate that oxidative stress play important role in pathogenesis of cancer. ${ }^{1}$

\section{Cardiovascular disease}

Oxidative stress in cardiovascular system may produce various cardiovascular diseases such as atherosclerosis, ischemic heart disease, hypertension, congestive heart failure, cardiac hypertrophy and cardiomyopathies by producing cell injury to cardiovascular tissue. Oxidative stress leads to change in cell wall permeability and alter cardiovascular cell function specially uptake of $\mathrm{Ca}^{+}$ion which is common denominator health and disease condition. ${ }^{1}$

\section{Lungs disease}

Reactive oxygen and nitrogen species are produced in large amount in lung by alveolar, bronchial and endothelial cells and phagocytes when they exposed to endogenous and exogenous oxidants such as cigarette smoke, mineral dust, radiation etc. which result redox imbalance responsible for the progression of idiopathic pulmonary fibrosis and other diffuse lung diseases. ${ }^{2}$

\section{Inflammatory disease}

Oxidative stress due to reactive oxygen and nitrogen species activates monocytes and macrophages for production of pro-inflammatory cytokine by depleting intracellular thiol compounds and activating nuclear factor $\mathrm{KB}(\mathrm{NF}-\mathrm{KB}){ }^{7}$

\section{Eye disease}

Oxidative stress responsible for cataract, glaucoma, diabetic retinopathy, macular degeneration (leading cause of blindness in the developed countries), autoimmune and inflammatory uveitis (group of potentially blinding diseases associated with immunological responses to unique 
retinal proteins), pseudoexofoliation syndrome (common age related fibrillopathy recognized by chronic deposition of abnormal pseudoexfoliation material on the anterior segment structures of the eye), retinitis pigmentosa (a heterogeneous group of inherited retinal disorders characterized by progressive photoreceptor apoptosis). ${ }^{8}$

\section{Neurological disorders}

The brain is more prone to oxidative stress due to its high consumption of oxygen and availability of polyunsaturated fatty acids which leads to change in permeability of cell results various neurological disorders like Alzheimer's disease etc. ${ }^{1}$

\section{ANTI-OXIDANT}

Anti-oxidant are the substances that significantly delays or inhibits oxidation of that substrate, when present at low concentrations compared with that of an oxidizable substrate. ${ }^{9}$ Human body produces large number of free radical which have role in pathogenesis of various disease hence body maintain redox balance by producing various anti-oxidant which can broadly divided in two groups i.e. enzymatic antioxidants and non-enzymatic anti-oxidants.

The enzymatic antioxidants are divided into primary and secondary enzymatic antioxidants. The primary enzymatic antioxidants such as glutathione peroxidase, catalase and superoxide dismutase prevent the formation of free radical by neutralizing them. Glutathione peroxidase reduces peroxides by forming selenols. Single molecule of catalase converts up to 6 billion molecules of hydrogen peroxide into water and molecular oxygen. Superoxide dismutase converts superoxide anions into hydrogen peroxide. The secondary enzymatic antioxidants such as glutathione reductase and glucose-6-phosphate dehydrogenase prevent the formation of free radical by generating reducing compound glutathione and NADPH respectively which neutralizes free radicals. The non-enzymatic antioxidants consist of vitamins (A, E, C), enzyme cofactors (Q10), minerals (zinc and selenium), peptides (glutathione), phenolic acids, and nitrogen compounds (uric acid). ${ }^{9}$

If the internal mechanism fails to control redox reaction disease condition may develop which can be overcome by providing external compound as antioxidant. Antioxidants are classified into primary or natural antioxidants and secondary or synthetic antioxidants. ${ }^{10}$

\section{Primary or natural anti-oxidant}

They are mainly polyphenolic compounds which inhibit free radical reaction by stabilizing free radicals. They are classified into mineral, vitamins and phytochemicals.

\section{Anti-oxidant minerals}

The minerals such as selenium, copper, iron, zinc and manganese are essential for enzymatic 
reaction because they act as co factor for these reactions. The decrease in concentration of these mineral causes oxidative stress which can be overcome by providing these minerals externally as antioxidant.

\section{Anti-oxidant vitamins}

Vitamin A, E and C play important role in control of redox reaction. If required to body can provide externally,

\section{Phytochemicals}

These are phenolic compounds which inhibit free radical reaction by stabilizing free radicals i.e. flavonoids, tannins, terpenoids, catechin, caretonpids etc.

\section{$>\quad$ Secondary or synthetic anti-oxidant}

These are synthetic phenolic compounds that inhibit free radical chain reaction by interacting with free radicals. They are classified as follows

* Butylated hydroxyl anisole (BHA).

* Butylated hydroxyl toluene (BHT).

* Propyl gallate (PG) and metal chelating agent (EDTA).

* Tertiary butyl hydroquinone (TBHQ).

* Nordihydro guaretic acid (NDGA).

\section{PLANTS HAVING ANTI-OXIDANT ACTIVITY}

A large number of medicinal plants and their purified constituents have shown antioxidant activity such as Ocimum sanctum, Piper cubeba, Allium sativum, Terminalia bellerica, Camellia sinensis, Zingiber officinale with significant therapeutic effect. The antioxidant property of plant is mostly due to the flavones, isoflavones, flavonoids, anthocyanin, coumarin, lignans, catechins and isocatechins. ${ }^{11}$ Some plant with highest antioxidant activity are mention below. ${ }^{12}$ (Table 7.1)

Table 1: Plants having anti-oxidant activity

\begin{tabular}{|c|c|c|c|c|}
\hline Sr.No. & Botanical Name & $\begin{array}{l}\text { Common } \\
\text { Name }\end{array}$ & $\begin{array}{l}\text { Part of } \\
\text { Plant }\end{array}$ & Phytochemical \\
\hline 1 & $\begin{array}{l}\text { Curcuma longa } \\
\text { Zingiberaeae }\end{array}$ & Turmeric & Leaf & $\begin{array}{l}\text { Curcumin, camphene, } \\
\text { eugenol, } \beta \text {-sitosterol }\end{array}$ \\
\hline 2 & $\begin{array}{l}\text { Coscuta reflexa } \\
\text { Convolvulaceae }\end{array}$ & Akashbela & Stem & $\begin{array}{l}\text { Flavonoids, coumarin, } \\
\text { bergenin }\end{array}$ \\
\hline 3 & $\begin{array}{l}\text { Daucus carota } \\
\text { Apiaceae }\end{array}$ & Carrot & Root & $\begin{array}{l}\text { Carotenes, carotenoids, } \\
\text { flavonoids }\end{array}$ \\
\hline 4 & $\begin{array}{l}\text { Embelica officinalis } \\
\text { Euphorbiaceae }\end{array}$ & Amla & Fruit & $\begin{array}{l}\text { Vitamin C, ellagic acid, } \\
\text { gallic acid, tannins }\end{array}$ \\
\hline 5 & $\begin{array}{l}\text { Foeniculum vulgare } \\
\text { Apiaceae }\end{array}$ & Fennel & Fruit & $\begin{array}{l}\text { Fenchone, anethole, } \\
\text { limonene, anisaldehyde }\end{array}$ \\
\hline 6 & Glycyrrhiza glabra & Liquorice & Root & Glycyrrhizin, glycyrrhizinic \\
\hline
\end{tabular}




\begin{tabular}{|c|c|c|c|c|}
\hline & Fabaceae & & & acid, liquiritin, isoliquritin \\
\hline 7 & $\begin{array}{l}\text { Momordica } \\
\text { charantia } \\
\text { Cucurbitaceae }\end{array}$ & Karela & $\begin{array}{l}\text { Root, } \\
\text { leaf, } \\
\text { fruit, } \\
\text { seed }\end{array}$ & $\begin{array}{l}\text { Stearic acid, triterpene, } \\
\text { glycosides }\end{array}$ \\
\hline 8 & $\begin{array}{l}\text { Mongifera indica } \\
\text { Anacardiacaeae }\end{array}$ & Mango & $\begin{array}{l}\text { Root, } \\
\text { leaf, } \\
\text { fruit }\end{array}$ & $\begin{array}{l}\text { Ellagic acid, gallic acid, } \\
\beta \text {-sitosterol, mangiferin }\end{array}$ \\
\hline 9 & $\begin{array}{l}\text { Ocimum } \\
\text { sanctumLabitae }\end{array}$ & Tulsi & Leaf & Eugenol, thymol, estragole \\
\hline 10 & $\begin{array}{l}\text { Psoralea corylifolia } \\
\text { Fabaceae }\end{array}$ & Babchi & Seed & $\begin{array}{l}\text { Monoterpene, essential oil, } \\
\text { fixed oil, resins }\end{array}$ \\
\hline 11 & $\begin{array}{l}\text { Santalum album } \\
\text { Santalaceae }\end{array}$ & Sandal & $\begin{array}{l}\text { Heart } \\
\text { wood, } \\
\text { bark }\end{array}$ & $\begin{array}{l}\text { Santalol, } \beta \text {-santalol, } \alpha \text { - } \\
\text { santalol, } \beta \text {-sitosterol. }\end{array}$ \\
\hline 12 & $\begin{array}{l}\text { Solanum nigrum } \\
\text { Solanaceae }\end{array}$ & Makoi & Leaf & $\begin{array}{l}\text { Flavonoids, steroids, } \\
\text { polyphenolic compound }\end{array}$ \\
\hline 13 & $\begin{array}{l}\text { Swertiac hirayita } \\
\text { Genteliaceae }\end{array}$ & Chirayita & $\begin{array}{l}\text { Whole } \\
\text { plant }\end{array}$ & Swertine, xanthone, chiratin \\
\hline 14 & $\begin{array}{l}\text { Withania somnifera } \\
\text { Solanaceae }\end{array}$ & Ashwagandha & $\begin{array}{l}\text { Root, } \\
\text { leaf, } \\
\text { seed }\end{array}$ & Withanoloids, withanine \\
\hline
\end{tabular}

\section{METHODS FOR EVALUATION OF ANTI-OXIDANT ACTIVITY}

Near about 29 of methods are available for evaluation anti-oxidant activity which can be used on the basis of involvement of free radical, solvent, and feasibility. These methods are divided into in-vitro methods (19) and in vivo methods (10) which are given below. ${ }^{13}$

\section{In-vitro methods}

$\checkmark \quad$ DPPH scavenging activity

$\checkmark \quad$ Hydrogen peroxide scavenging $\left(\mathrm{H}_{2} \mathrm{O}_{2}\right)$ assay

$\checkmark \quad$ Nitric oxide scavenging activity

$\checkmark \quad$ Peroxynitrite radical scavenging activity

$\checkmark \quad$ Trolox equivalent antioxidant capacity method/ABTS radical cation de-colorization assay

$\checkmark \quad$ Total radical-trapping antioxidant parameter (TRAP) method

$\checkmark \quad$ Ferric reducing-antioxidant power (FRAP) assay

$\checkmark \quad$ Superoxide radical scavenging activity (SOD)

$\checkmark \quad$ Hydroxyl radical scavenging activity

$\checkmark \quad$ Hydroxyl radical averting capacity (HORAC) method

$\checkmark \quad$ Oxygen radical absorbance capacity (ORAC)

$\checkmark \quad$ Reducing power method (RP)

$\checkmark \quad$ Phosphomolybdenum method 
$\checkmark \quad$ Ferric thiocyanate (FTC) method

$\checkmark \quad$ Thiobarbituric acid (TBA) method

$\checkmark \quad$ DMPD (N,N-dimethyl-p-phenylene diamine dihydrochloride)

$\checkmark \quad$ b-carotene linoleic acid method/conjugated diene assay

$\checkmark \quad$ Xanthine oxidase method

$\checkmark \quad$ Cupric ion reducing antioxidant capacity (CUPRAC) method

$\checkmark \quad$ Metal chelating

\section{In-vivo models}

$\checkmark \quad$ Ferric reducing ability of plasma

$\checkmark \quad$ Reduced glutathione (GSH) estimation

$\checkmark \quad$ Glutathione peroxidase (GSHPx) estimation

$\checkmark \quad$ Glutathione-S-transferase (GSt)

$\checkmark \quad$ Superoxide dismutase (SOD) method

$\checkmark \quad$ Catalase (CAT)

$\checkmark \quad$ c-Glutamyl transpeptidase activity (GGT)

$\checkmark \quad$ Glutathione reductase (GR) assay

$\checkmark \quad$ Lipid peroxidation (LPO) assay

$\checkmark \quad$ LDL assay

\section{REFERENCES}

1. FundaSibel Pala, Hakan Gurkan. The role of free radicals in ethiopathogenesis of diseases. Advances in Molecular Biology. 2008; (1): 1-9.

2. Bargagli E, Olivieri C, Bennett D, Prasse A, Muller-Quernheim J, Rottoli P. Oxidative stress in the pathogenesis of diffuse lung diseases: A review. Respiratory Medicine. 2009; 103: $1245-1256$.

3. Abheri Das Sarma, Anisur Rahaman Mallick, Ghosh AK. Free radicals and their role in different clinical conditions: An overview. International Journal of Pharma Sciences and Research. 2010; 1(3): 185-192.

4. Devasagayam TPA, Tilak JC, Boloor KK, Sane KS, Ghaskadbi SS, Lele RD. Free radicals and antioxidants in human health: Current status and future prospects. Journal of Association of Physicians of India. 2004; 52(10): 794-804.

5. Shafaq Noori. An overview of oxidative stress and antioxidant defensive system. Open Access Scientific Reports. 2012; 1 (8):1-9. 
6. Assim A. Alfadda, Sallam RM. Reactive oxygen species in health and disease. Journal of Biomedicine and Biotechnology. 2012: 1-14.

7. Iain LC Chapple. Role of free radicals and antioxidants in the pathogenesis of the inflammatory periodontal diseases. Journal of Clinical Pathology-molecular Pathology. 1996; 49 (5):M247-M255.

8. Oduntan OA, Mashige KP. A review of the role of oxidative stress in the pathogenesis of eye diseases. The South African Optometrist. 2011; 70(4): 191-199.

9. Yevgenia Shebis, David Iluz, Yael Kinel-Tahan, Zvy Dubinsky, Yaron Yehoshua. Natural antioxidants: Function and sources. Food and Nutrition Sciences. 2013; 4: 643649.

10. Hamid AA, Aiyelaagbe OO, Usman LA, Ameen OM, Lawal A. Antioxidants: Its medicinal and pharmacological applications. African Journal of Pure and Applied Chemistry. 2010; 4(8): 142-151.

11. Nooman A. Khalaf, Ashok K. Shakya, Atif Al-Othman, Zaha El-Agbar, Husni Farah. Antioxidant activity of some common plants. Turkish Journal of Biology. 2008; 32 (1):51-55.

12. Vivek Kumar Gupta and Surendra Kumar Sharma. Plants as natural antioxidant. Natural Product Radiance. 2006; 5(4): 326-334.

13. Md. Nur Alam, Nusrat Jahan Bristi, Md. Rafiquzzaman. Review on in vivo and in vitro methods evaluation of antioxidant activity. Saudi Pharmaceutical Journal. 2013; 21(2): 143-152.

AJPHR is

Peer-reviewed

monthly

Rapid publication

Submit your next manuscript at

editor@aiphr.com / editor.aiphr@gmail.com 